\title{
PENGARUH PENGGUNAAN SMARTPHONE PADA PEMBELAJARAN ONLINE TERHADAP HASIL BELAJAR SISWA DI SMPN 1 KAPUAS TIMUR KABUPATEN KAPUAS TAHUN PELAJARAN 2020/2021
}

\author{
RIZKY ARYA DINANSYAH ${ }^{1)}$ \\ ${ }^{1}$ Fakultas IImu Pendidikan, Universitas Palangka Raya
}

\begin{abstract}
ABSTRAK
Kehadiran smartphone selaku media pendukung proses belajar jadi sangat diperlukan buat pelaksanaan sistem tersebut. Diiringi dengan internet, kecanggihan smartphone untuk mengakses berbagai macam informasi akan lebih cepat dan mudah. Proses pembelajaran antara guru dan siswa juga akan lebih interaktif. Buat mengakses bermacam berbagai data hendak lebih kilat serta gampang. Proses pendidikan antara guru serta siswa pula hendak lebih interaktif. Dengan terdapatnya pandemi Covid- 19 mengganti seluruh rutinitas pembelajaran di sekolah. Siswa diharuskan untuk mengikuti pembelajaran jarak jauh dari rumah. Pemakaian smartphone pada masa pandemi Covid - 19 ini harus digunakan oleh siswa disebabkan diterapkan pendidikan secara online sehingga mengharuskan siswa wajib mempunyai smartphone selaku penunjang utama dalam belajar online. Tujuan dari penelitian ini adalah untuk mengetahui pengaruh penggunaan smartphone pada pembelajaran online terhadap hasil belajar siswa di SMPN 1 Kapuas Timur Kabupaten Kapuas tahun pelajaran 2020/2021.

Penelitian ini merupakan penelitian deskriptif kuantitatif. Populasi penelitiannya adalah siswa SMPN 1 Kapuas Timur Kabupaten Kapuas tahun pelajaran 2020/2021 sedangkan sampel penelitiannya adalah siswa kelas $7 \mathrm{~A}$ dan $8 \mathrm{~A}$ dengan jumlah keseluruhan sebanyak 60 siswa. Data didapatkan dari angket dan nilai UTS. Teknik analisis data menggunakan uji regresi.

Berdasarkan hasil penelitian dapat disimpulkan bahwa terdapat pengaruh penggunaan smartphone pada pembelajaran online terhadap hasil belajar siswa di SMPN 1 Kapuas Timur Kabupaten Kapuas tahun pelajaran 2020/2021. Berdasarkan hasil analisis uji $t$ diketahui bahwa terdapat pengaruh penggunaan smartphone pada pembelajaran online $(\mathrm{X})$ dan variabel hasil belajar (Y). Hal ini dibuktikan dengan hasil perhitungan uji t sebesar 4,616 sedangkan pada $t_{\text {tabel }}$ adalah 2,002 pada taraf signifikansi $5 \%$ yang berarti bahwa Ha diterima. Hasil uji koefisien determinasi diperoleh nilai sebesar $26,9 \%$ dan $73,1 \%$ merupakan faktor yang mempengaruhi variabel $\mathrm{Y}$ dari faktor lain yang tidak diteliti oleh peneliti. Hal ini memberikan gambaran bahwa semakin baik penggunaan smartphone pada pembelajaran online oleh siswa maka semakin meningkat hasil belajar siswa di SMPN 1 Kapuas Timur Kabupaten Kapuas tahun pelajaran 2020/2021.
\end{abstract}

Kata Kunci: Penggunaan Smartphone, Hasil Belajar 


\section{PENDAHULUAN}

Berdasarkan observasi awal dan informasi dari guru di SMPN 1 Kapuas Timur Kabupaten Kapuas penggunaan smartphone dikalangan siswa dilandasi oleh sebagian alasan, seperti hanya ingin mengikuti trend, ataupun buat lebih aktif di media sosial (Facebook, WhatsApp, Instagram, BBM, Line dan lain sebagainya), mencari data mengenai hobi dan sebagainya serta ada juga siswa yang memanfaatkan smartphone sebagai sumber belajar, mencari tambahan materi pelajaran, membagi data kepada teman sekelas mengenai tugas yang diberikan.

Memandang kegiatan siswa dalam memakai smartphone, bermacam kebijakan diterapkan oleh pihak sekolah kepada siswa antara lain sekolah mengizinkan siswa memakaismartphone. Adapun alasan pihak SMPN 1 Kapuas Timur Kabupaten Kapuas yang mengizinkan siswa buat memakai smartphone di lingkungan sekolah adalah kelebihan smartphone yang dapat dengan kilat mengakses data yang diperlukan, apalagi sebagian guru kelas memperbolehkan siswa memakai smartphone saat proses belajar mengajar berlangsung dengan alasan bisa mendukung proses pembelajaran.

Dengan terdapatnya pandemi Covid- 19 mengganti seluruh rutinitas pembelajaran di sekolah. Siswa diharuskan untuk mengikuti pembelajaran jarak jauh dari rumah.

Handayani (20121:54) berpendapat bahwa

"Virus covid-19 ini sangat berbahaya yang mana berdampak juga pada pelaksanaan pembelajaran di sekolah. Sekolah-sekolah banyak ditutup dan tidak diperbolehkan melakukan kegiatan belajar mengajar untuk mengurangi dan memutuskan rantai penyebaran virus covid-19, sehingga pembelajaran yang biasanya dilakukan secara langsung atau tatap muka sekarang dilakukan secara online dengan menggunakan smartphone dan laptop sebagai media yang digunakan siswa untuk dapat mengikuti pembelajaran yang dilakukan secara online atau disebut juga dengan pembelajaran daring".

Adanya perubahan proses pembelajaran dari luring menjadi daring yang disebabkan oleh virus korona, maka bisa dipastikan siswa akan memakai smartphone dalam mengikuti proses pembelajaran daring dari rumah (Imam, 2019). Pemakaian smartphone ini pastinya tidak lepas dari peran orangtua yang pada kehidupan sehari-hari sudah memberikan fasilitas tersebut kepada anak-anaknya terlalu dini (Pradevi, 2020).

Hasil observasi awal jumlah keseluruhan siswa yang ada di SMPN 1 Kapuas Timur Kabupaten Kapuas Tahun Pelajaran 2020/2021 adalah 171 orang dengan jumlah siswa per kelas sebagai berikut.

Tabel 1. Jumlah Siswa di SMPN 1 Kapuas Timur Kabupaten Kapuas Tahun Pelajaran $2020 / 2021$

\begin{tabular}{cccc}
\hline No & & Kelas & Jumlah \\
\hline 1 & Kelas 7A & 28 \\
\hline 2 & Kelas 7B & 28 \\
\hline 3 & Kelas 8A & 32 \\
\hline 4 & Kelas 8B & 31 \\
\hline 5 & Kelas 9A & 27 \\
\hline 6 & Kelas 9B & & 25 \\
\hline & & Jumlah & $\mathbf{1 7 1}$ \\
\hline
\end{tabular}

Berdasarkan latar belakang tersebut, maka tertarik untuk melakukan penelitian dengan judul Pengaruh Penggunaan Smartphone Pada Pembelajaran Online Terhadap Hasil Belajar Siswa di SMPN 1 Kapuas Timur Kabupaten Kapuas Tahun Pelajaran 2020/2021. 


\section{KAJIAN PUSTAKA}

\section{Pengaruh Penggunaan Smartphone Pada Pembelajaran Online}

Menurut Tim Penyusun KBBI (2012) smartphone adalah bentuk telepon seluler yang dapat berfungsi selayaknya komputer personal yang memiliki layar sentuh dan dipadukan oleh akses internet.

Menurut Sobon dan Mangundap (2019:92) bahwa:

"Smartphone adalah telepon yang internet enabled yang biasanya menyediakan fungsi Personal Digital Assistant (PDA), seperti fungsi kalender, buku agenda, buku alamat, kalkulator dan catatan. Dengan alasan itulah, maka smartphone disebut sebagai telepon cerdas. Smartphone adalah alat komunikasi yang memiliki kemampuan lebih dan memiliki perangkat keras dan perangkat lunak yang memiliki kemiripan dan fungsi yang canggih seperti komputer. Dengan kata lain smartphone adalah komputer kecil yang memiliki kemampuan untuk berkomunikasi, mencari data, email, bermain games, transfer data dan keuangan dan kegunaan lainnya yang dapat mempermudah aktivitas manusia".

Menurut Rahma (2015) smartphone adalah telepon yang menyediakan fitur yang berada di atas dan diluar kemampuan sederhana untuk membuat panggilan telepon. Smartphone dipahami sebagai ponsel dan bukan telepon rumah. Smartphone (telepon cerdas) adalah telepon genggam yang mempunyai kemampuan tingkat tinggi, kadangkadang dengan fungsi yang menyerupai komputer.

\section{Tinjauan Tentang Hasil Belajar}

Menurut Purwanto (2012:45) bahwa:

"Hasil belajar seringkali digunakan untuk ukuran dalam mengetahui seberapa jauh seseorang menguasai bahan yang sudah diajarkan. Hasil belajar merupakan pencapaian tujuan pendidikan pada siswa yang mengikuti proses belajar mengajar. Hasil belajar adalah perubahan yang mengakibatkan manusia berubah dalam sikap dan tingkah lakunya".

"Untuk menentukan hasil belajar dapat diukur dengan penilaian. Dengan demikian penilaian adalah proses memberikan atau menentukan nilai kepada objek tertentu berdasarkan suatu kriteria tertentu" (Sudjana, 2012: 112).

\section{METODE}

Jenis penelitian adalah penelitian yang bersifat deskriptif kuantitatif. Menurut Suryabrata (2013: 75) "Penelitian deskriptif adalah "penelitian yang bertujuan untuk membuat perencanaan sistematis aktual dan akurat mengenai faktor-faktor dan populasi dan daerah tertentu". Menurut Sugiyono (2012:57) "pendekatan yang digunakan dalam penelitian ini adalah pendekatan kuantitatif, artinya semua informasi atau data penelitian diwujudkan dalam bentuk angka yang dianalisis dengan statistik dan hasilnya dideskripsikan".

Penelitian ini dilaksanakan di SMP Negeri 1 Kapuas Timur Kabupaten Kapuas. Sampel yang digunakan adalah siswa siswa kelas Kelas VII dan VIII sebanyak 60 orang siswa. Teknik pengumpulan data menggunakan angket dan dokumentasi. Teknik analisa data menggunakan uji regresi. 


\section{HASIL DAN PEMBAHASAN}

\section{A. Uji Asumsi Klasik}

\section{Uji Normalitas}

Uji normalitas ini dilakukan untuk mengetahui apakah variabel $X$ dan $Y$ yang diteliti memiliki distribusi normal atau tidak normal. Uji normalitas distribusi data dalam penelitian ini menggunakan Kolmogorov-Smirnov dengan alat bantu SPSS. Ketentuan dalam perhitungan normalitas ini adalah apabila taraf signifikan $>0,05$ maka data tersebut normal, begitupun sebaliknya apabila taraf signifikan $<0,05$ maka data tersebut tidak normal.

Berikut hasil perhitungan uji normalitas dengan menggunakan SPSS.

\section{Normal P-P Plot of Regression Standardized Residual}

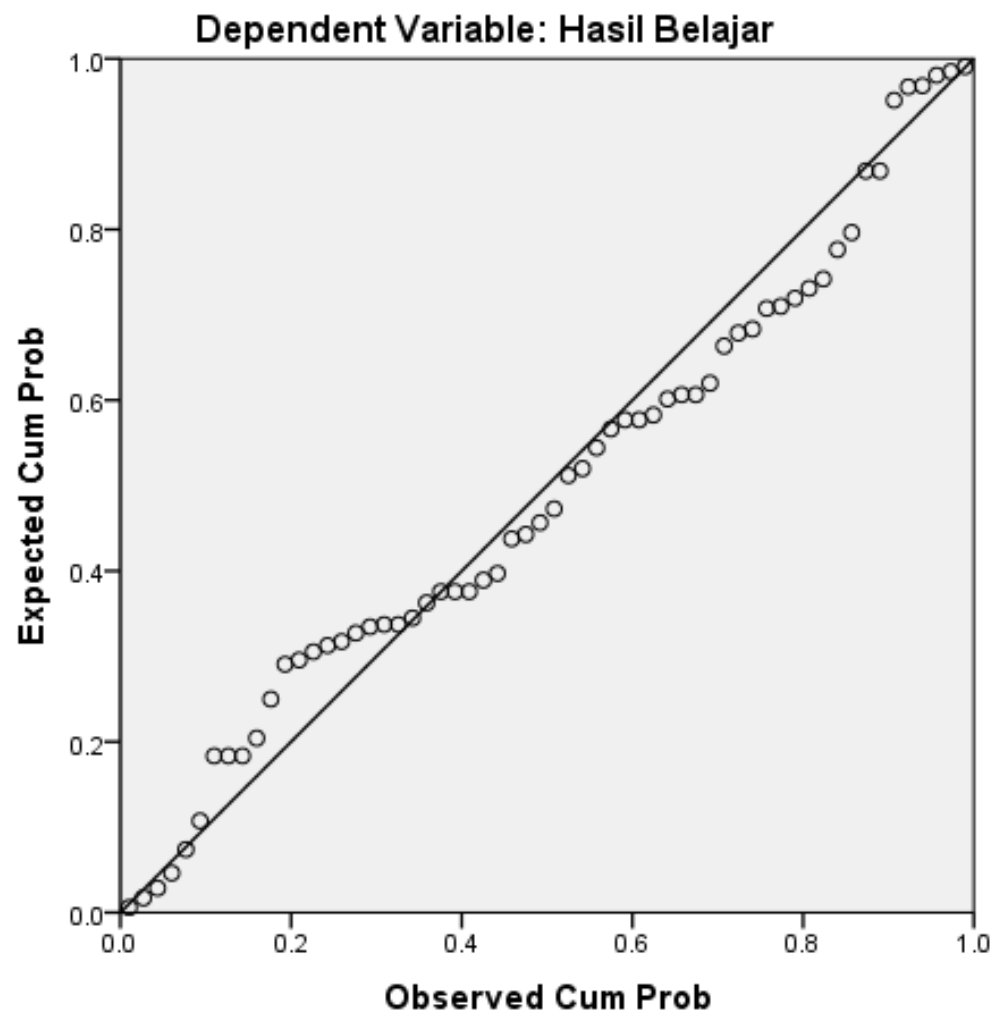

Gambar 1. Hasil Uji Normalitas menggunakan P Plot

Pada Gambar 1. data yang telah diolah memperlihatkan penyebaran data yang berada di sekitar garis diagonal dan mengikuti arah garis diagonal. Hal ini menunjukkan bahwa model regresi telah memenuhi asumsi normalitas. Untuk lebih meyakinkan hasil uji grafik, maka pada uji normaliltas ini dilengkapi dengan uji statistik, yaitu dengan menggunakan uji Kolmogorof-Smirnov pada $\alpha=0,05$ yang menunjukkan data tersebut normal. 


\section{Uji Homogenitas}

Pada uji homogenitas di lakukan untuk mengetahui apakah varian populasi adalah sama atau tidak.

Tabel 1. Hasil Uji Homogenitas

\begin{tabular}{|r|rr|r|rr|}
\hline Levene Statistic & df1 & df2 & Sig. \\
\hline 1.731 & & 1 & 118 & & .191 \\
\hline
\end{tabular}

Berdasarkan tabel diatas, tampak nilai sig yang diperoleh dari hasil uji homogenitas lebih besar dari nilai taraf nyata pengujian yaitu $0,191>0,05$ sehingga skor-skor pada variabel hasil belajar dan skor-skor variabel penggunaan smartphone pada pembelajaran online menyebar secara homogen.

\section{Uji Linieritas}

Uji linearitas bertujuan untuk mengetahui linear atau tidaknya sebaran data penelitian. Berdasarkan analisis data dengan bantuan program SPSS dapat diketahui uji linearitas antara variabel bebas (penggunaan smartphone pada pembelajaran online) dengan variabel terikatnya (hasil belajar) dilihat dari deviation from linierity. Menurut kriteria dasar pengambilan kesimpulan jika nilai signifikansi pada deviation from linierity $>0,05$ maka terdapat hubungan yang linear antara variabel bebas dengan variabel terikatnya. Dengan melihat tabel output ANOVA tabel seperti berikut:.

Tabel 2. Uji Linieritas

\begin{tabular}{|c|c|c|c|c|c|c|}
\hline \multicolumn{7}{|c|}{ ANOVA Table } \\
\hline & & $\begin{array}{l}\text { Sum of } \\
\text { Squares }\end{array}$ & df & $\begin{array}{l}\text { Mean } \\
\text { Square }\end{array}$ & $\mathrm{F}$ & Sig. \\
\hline \multirow{5}{*}{$\begin{array}{l}\text { Hasil Belajar } \\
\text { * } \\
\text { Penggunaan } \\
\text { Smartphone } \\
\text { Pada } \\
\text { Pembelajaran } \\
\text { Online }\end{array}$} & $\begin{array}{l}\text { Between (Combined) } \\
\text { Groups }\end{array}$ & 1340.150 & 19 & 70.534 & 2.509 & .007 \\
\hline & Linearity & 662.249 & 1 & 662.249 & 23.558 & .000 \\
\hline & $\begin{array}{l}\text { Deviation } \\
\text { from } \\
\text { Linearity }\end{array}$ & 677.901 & 18 & 37.661 & 1.340 & .216 \\
\hline & Within Groups & 1124.433 & 40 & 28.111 & & \\
\hline & Total & 2464.583 & 59 & & & \\
\hline
\end{tabular}

Dari hasil perhitungan didapatkan nilai deviation from linierity sebesar 0,216 $>0,05$ untuk penggunaan smartphone pada pembelajaran online terhadap hasil belajar. Dalam penelitian ini terbukti bahwa penggunaan smartphone pada pembelajaran online terhadap hasil belajar bersifat linear.

\section{B. Analisis Data}

Nilai signifikan (sig), diperoleh nilai Regression Residual Sig adalah 0,000 lebih besar dari 0,05. Maka dapat disimpulkan bahwa ada hubungan linear secara signifikan antara variabel minat belajar $(\mathrm{X})$ dengan variabel hasil belajar $(\mathrm{Y})$. Berdasarkan tabel ANOVA, diperoleh nilai $F_{\text {hitung }}$ sebesar 21,311 dan $F_{\text {tabel }}$ sebesar 4,01 . Karena $F_{\text {hitung }}>F_{\text {tabel }}$ maka persamaan regresi yang dipergunakan dapat diterapkan dalam analisis data. Hal ini berarti 
bahwa variabel penggunaan smartphone pada pembelajaran online berpengaruh terhadap hasil belajar siswa.

\section{PEMBAHASAN}

Penelitian yang dilakukan di SMPN 1 Kapuas Timur Kabupaten Kapuas tahun pelajaran 2020/2021 bertujuan untuk mengetahui pengaruh penggunaan smartphone pada pembelajaran online terhadap hasil belajar siswa di SMPN 1 Kapuas Timur Kabupaten Kapuas tahun pelajaran 2020/2021. Pengaruh yang terlihat dari kedua aspek tersebut dapat dikatakan memiliki pengaruh antara satu dengan yang lainnya.

Berdasarkan hasil penelitian yang dilakukan, hasil penelitian mengungkapkan bahwa antara variabel penggunaan smartphone pada pembelajaran online terhadap hasil belajar siswa berpengaruh positif secara signifikan dengan nilai signifikan 0,000 lebih besar dari 0,05 , karena nilai $t_{\text {hitung }}=4,616>t_{\text {tabel }}=2,002$. Maka dengan demikian Ha diterima dan Ho ditolak. Sehingga, persamaan regresi yang dipergunakan dapat diterapkan dalam analisis data. Maka dapat disimpulkan bahwa terdapat pengaruh penggunaan smartphone pada pembelajaran online terhadap hasil belajar terhadap hasil belajar siswa di SMPN 1 Kapuas Timur Kabupaten Kapuas tahun pelajaran 2020/2021.

Berdasarkan perhitungan uji koefisien determinasi seperti dilihat pada Tabel 10. menunjukkan nilai korelasi $(R)$ yaitu sebesar 0,518 dan besarnya persentase pengaruh variabel bebas terhadap variabel terikat yang disebut koefisien determinasi yang merupakan hasil pengkuadratan R. Pada tahap ini peneliti menguji hipotesis untuk mengetahui seberapa besar atau berapa persen varians variabel terikat yang dijelaskan oleh variabel bebas. Oleh karena itu, peneliti ingin mengetahui lebih jauh mengenai apakah secara keseluruhan variabel bebas berpengaruh secara signifikan terhadap variabel terikat, dengan melihat signifikan atau tidaknya koefisien regresi dari variabel bebas. Langkah pertama peneliti menganalisis adanya pengaruh penggunaan smartphone pada pembelajaran online terhadap hasil belajar siswa ataukah tidak. Peneliti melihat besaran $R$ Square untuk mengetahui berapa persen (\%) varian variabel terikat yang dijelaskan oleh variabel bebas.

Berdasarkan hasil perhitungan hasil uji koefisien Determinasi $(R)$ variabel $X$ dan $Y$, diketahui bahwa $R$ square dari variabel penggunaan smartphone pada pembelajaran online sebesar 0,083 . Hal ini berarti, variabel penggunaan smartphone pada pembelajaran online memberikan kontribusi sebesar $26,9 \%$ bagi perubahan variabel hasil belajar. Sedangkan $73,1 \%$ sisanya dipengaruhi oleh variabel lain diluar penelitian.

\section{SIMPULAN DAN SARAN}

Kesimpulan yang dapat diambil berdasarkan hasil penelitian ini adalah terdapat pengaruh penggunaan smartphone pada pembelajaran online terhadap hasil belajar siswa di SMPN 1 Kapuas Timur Kabupaten Kapuas tahun pelajaran 2020/2021. Berdasarkan hasil analisis uji $t$ diketahui bahwa terdapat pengaruh penggunaan smartphone pada pembelajaran online $(X)$ dan variabel hasil belajar $(Y)$. Hal ini dibuktikan dengan hasil perhitungan uji t sebesar 4,616 sedangkan pada $t_{\text {tabel }}$ adalah 2,002 pada taraf signifikansi $5 \%$ yang berarti bahwa Ha diterima. Hasil uji koefisien determinasi diperoleh nilai sebesar 26,9\% dan $73,1 \%$ merupakan faktor yang mempengaruhi variabel $Y$ dari faktor lain yang tidak diteliti oleh peneliti. Hal ini memberikan gambaran bahwa semakin baik penggunaan smartphone pada pembelajaran online oleh siswa maka semakin meningkat hasil belajar siswa di SMPN 1 Kapuas Timur Kabupaten Kapuas tahun pelajaran 2020/2021.

Saran yang dapat diberikan adalah Bagi Guru, diharapkan guru dapat lebih kreatif dan inovatif dalam memberikan pembelajaran secara daring dan lebih menguasai penggunaan teknologi pembelajaran daring seperti menggunakan smartphone pada pembelajaran online secara positif. 


\section{DAFTAR PUSTAKA}

[1] Handayani, E. S. 2021. Penggunaan Smartphone Terhadap Hasil Belajar Siswa Selama Pandemi Covid-19 di SDN 015 Sungai Pinang. Bina Gogik, 8(1): 54-61.

[2] Imam, A. 2019. Pengaplikasian Smartphone sebagai Media Komunikasi Interpersonal di Kalangan Pegawai Kementerian Agama Kabupaten Aceh Barat. International Journal of Islamic Studies and Social Sciences, 1(2), 343-369.

[3] Pradevi, A. P. 2020. Hubungan Pengawasan Orang Tua dalam Penggunaan Gadget dengan Kemampuan Empati Anak. Jurnal Pendidikan Anak, 9 (1): 49-56.

[4] Pradevi, A. P. 2020. Hubungan Pengawasan Orang Tua dalam Penggunaan Gadget dengan Kemampuan Empati Anak. Jurnal Pendidikan Anak, 9 (1): 49-56.

[5] Rahma, A. 2015. Pengaruh Penggunaan Smartphone Terhadap Aktifitas Kehidupan Siswa. Jom Fisip, 2(2): 1-12.

[6] Sobon, K., Mangundap, J. M. 2019. Pengaruh Penggunaan Smartphone Terhadap Hasil Belajar Siswa Sekolah Dasar Di Kecamatan Mapanget, Kota Manado. Jurnal Inovasi Pendidikan dan Pembelajaran Sekolah Dasar, 3(1): 52-64.

[7] Sudjana, N. 2012. Penilaian Hasil Proses Belajar Mengajar. Bandung: Remaja Rosdakarya.

[8] Sugiyono. 2012. Metode Penelitian Pendidikan Pendekatan Kuantitatif, Kualitatif, dan $R \& D$. Bandung: Alfabeta.

[9] Suryabarata, S. 2013. Metodologi Penelitian. Jakarta:Rajawali Pers.

[10] Tim Penyusun KBBI. 2012. Kamus Besar Bahasa Indonesia Pusat. Bahasa Edisi Keempat. Jakarta: Gramedia Pustaka Utama. 